\title{
PENGGUNAAN KALIMAT EFEKTIF LAPORAN PRAKTIK KERJA INDUSTRI SISWA KELAS XI SMK NEGERI 2 CURUP TIMUR
}

\author{
Dian Sistia Rini \\ diansistia.rini@yahoo.com \\ Guru SMK Negeri 2 Curup
}

\begin{abstract}
Abstrak
Tujuan penelitian ini untuk mendeskripsikan penggunaan kalimat efektif laporan praktik kerja industri kelas XI SMK Negeri 2 Curup Timur. Latar belakang penelitian ini adalah ketertarikan peneliti terhadap laporan praktik kerja industri. Metode yang digunakan dalam penelitian ini adalah metode deskriptif. Data penelitian ini berupa ujaran tulis siswa ketika menulis laporan praktik kerja industri siswa. Sumber data berupa bagian pendahuluan laporan praktik kerja industri. Teknik analisis data dianalisis dengan membaca laporan siswa, mengidentifikasi, memberi nomor, verifikasi, dan menarik kesimpulan. Hasil penelitian laporan praktik kerja industri siswa yang diteliti terdapat 64 buah penyimpangan kalimat efektif. aspek ketepatan yakni 28 buah data, kelogisan 18 buah data, kepaduan 8 buah data, kehematan 7 buah data, dan kesatuan 1 buah data. Data tersebut memperlihatkan bahwa laporan praktik kerja industri siswa, masalah kalimat efektif belum seluruhnya diterapkan dengan benar di laporan praktik kerja industri siswa.
\end{abstract}

Keywords: kalimat efektif, prakerin, SMK

\section{PENDAHULUAN}

Penggunaan bahasa berkenaan dengan pemakaian dan pengembangan kalimat koherensi atau kohesi penggunaan secara efektif kontruksi kalimat kompleks (kalimat majemuk), kalimat tunggal, sederhana, unsur kalimat, jenis kalimat, dan pengefektifan urutan dan fungsi kata, artikel, kata ganti, kata depan. Pengembangan kalimat ini sangat bergantung pada keterampilan penulis untuk memanfaatkan secara tepat jenis dan bentuk kalimat yang digunakan dalam tulisan.

Dalam pengembangan kalimat
efektif perlu dibangun dengan
memperhatikan unsur kesatuan dan
kepaduan sebagai salah satu syarat
pembangunan kalimat yang baik. Kajian
rektorika kalimat berkaitan dengan kajian tata bahasa, yang membawa kalimat pada tahap dapat diterima atau dipahami pembaca, di sisi lain, rektorika akan membawa kalimat menjadi lebih jelas, lebih tepat, dan lebih indah dalam bentuk dan rangkaiannya, oleh karena itu, rektorika lebih erat kaitannya dengan kebutuhan perpaduan dan pilihan kata (diksi) yang tepat.

Salah satu keterampilan yang harus dikuasai oleh siswa adalah keterampilan menulis kalimat efektif. Keterampilan menulis kalimat efektif adalah keterampilan yang membutuhkan latihan sebagai usaha untuk meningkatkan dan mengembangkan keterampilan menulis kalimat efektif, oleh sebab itu, keterampilan ini sangat perlu. Dengan keterampilan menulis kalimat efektif seseorang dapat merekam, melaporkan, memberitahu- 
kan, menyakinkan, dan mempengaruhi orang lain. Dalam akhir pengajaran siswa diharapkan terampil berbahasa, memiliki pengetahuan, serta mampu menggunakan bahasa untuk berkomunikasi.

Berdasarkan pengalaman dan pengamatan penulis selama lima tahun (dari tahun 2007-2012), pengajaran menulis lebih menitikberatkan pada teori, bukan pada praktiknya. Walaupun telah disadari bahwa keterampilan ini merupakan keterampilan yang sangat penting untuk dikuasai, keterampilan menulis kurang mendapat perhatian dari guru mata pelajaran, padahal keterampilan menulis kalimat efektif tidak tampak pada status keberadaanya, nilai fungsinya, dan proses kegiatannya, melainkan pada wujud yang dihasilkannya. Kesulitan tersebut lebih jelas, dikemukakan oleh Akhadiah, dkk. (1990: 36) sebagai berikut;

"Menuangkan buah pikiran secara teratur dan teroganisir ke dalam sebuah tulisan sehingga pembaca dapat mengikuti dan memahami jalan pikiran seseorang tidaklah mudah. Banyak orang yang fasih berbicara namun kurang mampu menuangkan idenya secara tertulis. Kalaupun ahli-ahli bicara itu mampu menuliskan idenya dengan baik, biasanya hal ini terjadi melalui latihan yang intensif, baik secara formal maupun nonformal. Hal ini wajar, karena kemampuan menulis merupakan hasil proses belajar dan ketekunan berlatih".

Keterampilan menulis yang harus dikuasai oleh siswa SMK minimal memiliki kemampuan menuangkan idea atau gagasan secara logis, dengan menggunakan EYD (Ejaan Yang Disempurnakan), pilihan kata, menyusun kalimat efektif dan menyusun paragraf, serta merangkai paragraf menjadi sebuah wacana. Kemampuan membuat karangan utuh dari pengalaman pribadi yang mengesankan, menyusun surat, dan membuat laporan dari berbagai macam kegiatan akan memudahkan anak untuk mengembangkan diri pada menulis lanjut.

Berdasarkan fenomena tersebut, pada bagian pendahuluan laporan Praktik Kerja Industri yang dikerjakan oleh siswa masih bermasalah ketika dikaji kesesuaiannnya dengan penggunaan bahasa Indonesia. Laporan bagian pendahuluan Praktik Kerja Industri siswa SMK Negeri 2 Curup Timur masih belum tepat dengan penggunaan kalimat efektif. Hal ini bertentangan dengan kondisi ideal misi dan visi sekolah karena Praktik Kerja Industri adalah hubungan kerja sama antara dunia kerja dan industri menjadi tanggung jawab bersama untuk meningkatkan mutu. Berdasarkan fakta tersebut penggunaan bahasa Indonesia dalam bagian pendahuluan laporan praktik kerja industri menjadi sangat penting untuk diteliti, dan rumusan masalah yang penulis rumuskan adalah kemampuan menggunakan kalimat efektif sehingga Penggunaan Kalimat Efektif Laporan Praktik Kerja Industri Siswa Kelas XI SMK Negeri 2 Curup Timur dikaji secara khusus dari aspek kalimat efektif.

\section{METODE PENELITIAN}

Metode yang digunakan dalam penelitian ini adalah deskriptif. Penelitian ini dilakukan di sekolah, Jalan Duku Ulu No. 10 Kelurahan Talang Ulu Curup-Bengkulu dengan penggunaan kalimat efektif laporan praktik kerja industri siswa kelas XI SMK Negeri 2 Curup Timur, dengan waktu penelitian 
dimulai dari bulan Juni 2015 hingga Agustus 2015. Data penelitian adalah berupa tulisan siswa dalam laporan praktik kerja industri siswa kelas XI SMK Negeri 2 Curup Timur. Sumber data penelitian adalah 20 laporan praktik kerja industri siswa kelas XI SMK Negeri 2 Curup Timur. Teknik yang digunakan untuk mengumpulkan data adalah teknik dokumentasi yaitu teknik mengumpulkan dokumen dari laporan praktik kerja industri siswa.

Teknik analisis data ini dilakukan dengan langkah-langkah dalam laporan praktik kerja industri siswa melalui langkah-langkah berikut ini:

Membaca laporan praktik kerja industri Siswa, dan (2) Mengidentifikasi setiap data penelitian yaitu dari aspek kesatuan dengan syarat; satu ide pokok, aspek kepaduan (koherensi) dengan syarat; kata, frasa, klausa, tanda baca, fungsi sintaksis (S-P-O-Pel-Ket), aspek keparalelan dengan syarat; unsur pertama unsur kedua verba, unsur pertama nomina unsur kedua nomina, aspek ketepatan dengan syarat; satu kata, satu frasa, satu idiom, satu tanda baca, aspek kehematan dengan syarat; kata tidak mubazir, tidak menggulang subjek, tidak menjamakkan kata, aspek kelogisan dengan syarat; struktur kalimat, tanda baca, kata atau frasa.

\section{HASIL DAN PEMBAHASAN}

\section{A. Hasil Penelitian}

Penelitian ini dilaksanakan di kelas XI SMK Negeri 2 Curup Timur. Jumlah sampel dalam penelitian ini 20 laporan praktik kerja industri siswa. Hal ini karena laporan praktik kerja industri siswa banyak yang hilang dan sebagian lagi sudah dikembalikan lagi kepada siswa. Selain itu dengan jumlah yang relatif sedikit dapat membantu peneliti dalam kemampuan waktu, tenaga, dan dana yang dibutuhkan.

Berdasarkan hasil analisis terhadap 20 laporan praktik kerja industri siswa masih ditemukan adanya penyimpangan pengunaan kalimat efektif bagian pendahuluan laporan praktik kerja industri siswa. Penyimpangan Pengunaan yang dimaksud dalam penelitian ini diklasifikasikan ke dalam kalimat efektif harus memenuhi enam aspek, yaitu adanya kesatuan, kepaduan, keparalelan, ketepatan, kehematan, dan kelogisan. Secara lengkap, pengunaan itu disajikan pada Tabel berikut ini.

Tabel 1 Rekapitulasi Penyimpangan Kalimat EfektifSiswa Kelas XI SMK Negeri 2 Curup Timur

\begin{tabular}{|l|l|l|}
\hline No & Kalimat Efektif & Jumlah \\
\hline 1 & Kesatuan & 1 \\
\hline 2 & Kepaduan & 8 \\
\hline 3 & Keparalelan & 2 \\
\hline 4 & Ketepatan & 28 \\
\hline 5 & Kehematan & 7 \\
\hline 6 & Kelogisan & 18 \\
\hline Jumlah & 64 \\
\hline
\end{tabular}

Seperti yang tertera pada tabel 1 di atas, dari 20 laporan praktik kerja industri siswa yang diteliti terdapat 64 penyimpangan pengunaan kalimat efektif. Dari jumlah itu, jenis penyimpangan pengunaan kalimat efektif terbesar terjadi pada aspek ketepatan, yakni 28 data. pada urutan kedua terbesar penyimpangan pengunaan kalimat efektif terjadi pada kelogisan, yakni 18 data. Pada urutan ketiga terbesar penyimpangan pengunaan kalimat efektif terjadi pada kepaduan yakni 8 data. Pada urutan 
keempat terbesar penyimpangan pengunaan kalimat efektif terjadi pada kehematan, yakni 7 data. Pada urutan kelima terbesar penyimpangan pengunaan kalimat efektif terjadi pada keparalelan, yakni 2 data. Pada urutan keenam terkecil penyimpangan penggunaan kalimat efektif terjadi pada kesatuan, yakni 1 data.

Data tersebut memperlihatkan bahwa laporan praktik kerja industri siswa, masalah kalimat efektif belum sepenuhnya diterapkan dengan benar. Hal ini tebukti dari 64 bentuk penyimpangan pengunaan kalimat efektif. Jumlah penyimpangan pengunaan kalimat efektif ini dikaitkan dengan data laporan praktik kerja industri siswa yang diteliti, hasilnya dapat dilihat pada Tabel berikut.

Tabel 2 Penyimpangan Penggunaan Kalimat EfektifBerdasarkan Data Laporan Praktik Kerja Industri Siswa

\begin{tabular}{|c|c|c|c|c|c|c|c|}
\hline Data & Kesatuan & Kepaduan & Keparalelan & Ketepatan & Kehematan & Kelogisan & Jumlah \\
\hline $1 \mathrm{~A}$ & - & 1 & 1 & 1 & - & 2 & 5 \\
\hline $2 \mathrm{~B}$ & - & - & - & 2 & 1 & 1 & 4 \\
\hline $3 \mathrm{C}$ & - & - & - & 1 & 2 & 2 & 5 \\
\hline $4 \mathrm{D}$ & - & - & - & 2 & 1 & 1 & 4 \\
\hline $5 E$ & - & 2 & - & - & 1 & 1 & 4 \\
\hline $6 \mathrm{~F}$ & - & 1 & 1 & 1 & - & 2 & 5 \\
\hline $7 \mathrm{G}$ & - & - & - & 1 & - & 2 & 3 \\
\hline $8 \mathrm{H}$ & - & - & - & - & 1 & - & 1 \\
\hline 91 & - & 1 & - & 3 & - & - & 4 \\
\hline $10 \mathrm{~J}$ & 1 & - & - & 4 & - & 1 & 6 \\
\hline $11 \mathrm{~K}$ & - & - & - & 1 & - & 2 & 3 \\
\hline $12 \mathrm{~L}$ & - & - & - & 3 & 1 & 1 & 5 \\
\hline $13 \mathrm{M}$ & - & - & - & 2 & - & 1 & 3 \\
\hline $14 N$ & - & - & - & - & - & - & 0 \\
\hline 150 & - & - & - & 2 & - & - & 2 \\
\hline $16 P$ & - & 2 & - & 1 & - & - & 3 \\
\hline $17 \mathrm{Q}$ & - & - & - & 2 & - & - & 2 \\
\hline $18 \mathrm{R}$ & - & - & - & 1 & - & - & 1 \\
\hline $19 \mathrm{~S}$ & - & 1 & - & - & - & 1 & 2 \\
\hline $20 \mathrm{~T}$ & - & - & - & 1 & - & 1 & 2 \\
\hline Jumlah & 1 & 8 & 2 & 28 & 7 & 18 & 64 \\
\hline
\end{tabular}

Tabel 2 memperlihatkan bahwa dari 20 laporan praktik kerja industri siswa yang diteliti, penyimpangan pengunaan kalimat efektif yang terbesar terdapat pada data 10 hal ini terbukti dari 6 kasus, penyimpangan pengunaan kalimat efektif berikutnya yang merupakan urutan kedua tedapat pada data 1 , data 3 , data 6 , dan data 12 hal ini terbukti dari 5 kasus, penyimpangan pengunaan kalimat efektif ketiga terdapat pada data 2 , data 4 , data 5 , dan data 9 hal ini terbukti dari 4 kasus, penyimpangan pengunaan kalimat efektif keempat terdapat pada data 7, data 11 , dan data 16 hal ini terbukti dari 
3 kasus, penyimpangan pengunaan kalimat efektif kelima terdapat pada data 15 , data 17 , data 19 , dan data 20 hal ini terbukti dari 2 kasus, penyimpangan pengunaan kalimat efektif keenam terdapat pada data 18 dan data 14 hal ini terbukti dari 1 kasus dan 0 kasus.

$$
\text { Pada bagian berikut secara }
$$

berturut-turut akan disajikan hasil analisis penyimpangan pengunaan kalimat efektif yang terjadi pada laporan praktik kerja industri siswa yang diteliti, berupa penyimpangan pengunaan kesatuan, kepaduan (koherensi), keparalelan, ketepatan, kehematan, dan kelogisan. Contoh-contoh kalimat yang dimaksudkan adalah:

(1) Kepaduan (koherensi)

Hal ini dibuktikan melalui contoh kutipan data 1/A berikut;

"Sekolah Menengah Kejuruan adalah merupakan suatu sekolah yang menerapkan kurikulum keterpaduan antara lembaga pendidikan dengan dunia kerja dan industri."

(2) Keparalelan

Hal ini dibuktikan melalui contoh kutipan data 1/A berikut;

"Agar lingkungan sekitar bengkel terlihat indah dan rapi maka kita harus membersihkannya setiap hari dan membereskan peralatan kerja sehabis bekerja."

(3) Ketepatan

Hal ini dibuktikan melalui contoh kutipan data 1/A berikut;

"Serta agar siswa siswi SMK mengetahui proses keotomotifan didunia luar."

(4) Kelogisan

Hal ini dibuktikan melalui contoh kutipan data 1/A berikut;

"Namun secara umum yang kita kenal selama ini hanya pelaksanaan praktek industri yang disebut prakerin, padahal itu merupakan bagian dari prakerin.

"Secara umum prekerin dilakukan secara blok realis dimana sejumlah siswa kelas melaksanakan prakerin secara bersama dengan jumlah waktu yang sama pada beberapa perusahaan."

\section{B. Pembahasan}

Berdasarkan hasil penelitian mengenai penyimpangan penggunaan kalimat efektif terhadap 20 laporan praktik kerja industri siswa, ditemukan bahwa terdapat dua aspek dalam 20 laporan praktik kerja industri siswa dengan jumlah terbanyak terdapat pada aspek 4 yaitu menjelaskan ketepatan kalimat, kemudian jumlah terbanyak kedua yaitu pada aspek 6 tentang kelogisan kalimat, sementara itu untuk aspek terbanyak ketiga pada aspek 2 tentang kepaduan kalimat dan 5 tentang kehematan kalimat, sementara aspek terbanyak keempat pada aspek 3 tentang keparalelan kalimat, aspek terakhir yang ditemukan paling sedikit dari aspek yang lainnya yaitu aspek 1 tentang kesatuan kalimat.

Hasil temuan tersebut dapat menjelaskan bahwa keberadaan penggunaan kalimat efektif pada aspek 1 yang digunakan dalam laporan praktik kerja industri siswa, masih mengalami penyimpangan atau belum seluruhnya sesuai dengan penggunaan kalimat efektif. Dalam praktik di lapangan baik dalam wacana lisan maupun tulisan, masih banyak penggunaan kalimat efektif yang mengabaikan masalah ketepatan pemakaian unsur-unsur pembentuk kalimat. Akibatnya, kalimat 
yang dihasilkan pun tidak tinggi kualitasnya.

Hasil temuan tersebut dapat menjelaskan bahwa keberadaan aspek 1 dan Kecenderungan penyimpangan penggunaan kalimat efektif pada laporan praktik kerja industri siswa tergambar pada data 10 , data 1 , data 4 , data 6 , data 13 , data 15 , dan data 20 , sehingga pada aspek 1 dan aspek 3 ini menjadi aspek yang paling sedikit dibandingkan keempat aspek yang lainnya. Selain itu jika dilihat dari hasil perhitungan, aspek 4 dan aspek 6 menjadi aspek yang memiliki jumlah terbanyak, maka dapat disimpulkan bahwa penulisan laporan praktik kerja industri siswa masih banyak menyimpang dari syarat penulisan kalimat efektif. Selain ditemukannya aspek di atas, penulis juga menemukan hasil mengenai aspek 2 dan aspek 5 dengan urutan jumlah terbanyak ketiga, keberadaan aspek 2 dan aspek 5 bagi sebagian penulis laporan praktik kerja industri siswa penggunaan kalimat efektif dianggap sebagian penulis tidak harus ada dalam penulisan laporan praktik kerja industri siswa yang ditulisnya.

Berdasarkan hasil temuan terhadap laporan praktik kerja industri siswa bahwa kecenderungan penyimpangan penggunaan kalimat efektif tergambar pada setiap aspek penggunaan kalimat efektif. Pada aspek 1 kecenderungan penyimpangan penggunaan kalimat efektif pada laporan praktik kerja industri siswa tergambar pada data 10 laporan praktik kerja industri siswa. Pada aspek 2 kecenderungan penyimpangan penggunaan kalimat efektif pada laporan praktik kerja industri siswa tergambar pada data 1 , data 5 , data 6 , data 8 , data 9 , data 16 , data 18, dan data 19 laporan praktik kerja industri siswa. Pada aspek 3 kecenderungan penyimpangan penggunaan kalimat efektif pada laporan praktik kerja industri siswa tergambar pada data 1 , data 4 , data 6 , data 13 , data 15 , dan data 20. Pada aspek 4 kecenderungan penyimpangan penggunaan kalimat efektif pada laporan praktik kerja industri siswa tergambar pada data 1 , data 2 , data 3 , data 4 , data 6 , data 7 , data 8 , data 9 , data 10 , data 11 , data 12 , data 13 , data 14 , data 15 , data 16 , data 17 , data 18 , data 19 , dan data 20 . Pada aspek 5 kecenderungan penyimpangan penggunaan kalimat efektif pada laporan praktik kerja industri siswa tergambar pada data 1 , data 2 , data 3 , data 4 , data 5 , data 7 , data 8 , data 11 , data 12 , data 13, dan data 15. Pada aspek 6 kecenderungan penyimpangan penggunaan kalimat efektif pada laporan praktik kerja industri siswa tergambar pada data 1 , data 2 , data 3 , data 4 , data 5 , data 6 , data 7 , data 10 , data 11 , data 12 , data 13, data 17, data 19, dan data 20.

Berdasarkan hasil analisis dapat disimpulkan bahwa di dalam bagian pendahuluan laporan praktik kerja industri siswa penyimpangan penggunaan kalimat efektif didasarkan pada perbedaan aspek yang menjadi syarat agar kalimat menjadi efektif, meskipun terdapat kesamaan penyajian yang disajikan secara tidak langsung dengan tujuan komunikatif memberikan latar belakang informasi yang diperlukan bagi pembaca agar dapat memahami topik penelitian yang diteliti. Artinya, dalam setiap kalimat hanya ada satu topik atau satu maksud utama penulis atau pembicara, dan maksud itu harus dapat dikenali dan dipahami oleh pembaca atau pendengar. 


\section{SIMPULAN}

Berdasarkan hasil penelitian dan pembahasan dapat disimpulkan bahwa kalimat efektif yang digunakan di dalam bahasa laporan praktik kerja industri siswa ternyata belum seluruhya sejalan dengan kaidah kalimat efektif yang benar. Hal ini dapat dilihat dari aspek yang diteliti sebagai berikut; (1) Aspek ketepatan kalimat yang digunakan pada laporan praktik kerja industri siswa dan memiliki jumlah terbanyak (urutan pertama). Dari kalimat yang di analisis yang memenuhi syarat ketepatan kalimat berjumlah 4 kalimat. Yang tidak memenuhi penggunaan kalimat efektif berjumlah 28 kalimat. (2) Aspek kelogisan kalimat yang digunakan pada laporan praktik kerja industri siswa dan memiliki jumlah terbanyak (urutan kedua). Dari kalimat yang di analisis yang memenuhi syarat kelogisan kalimat berjumlah 3 kalimat. yang tidak memenuhi penggunaan kalimat efektif berjumlah 18 kalimat. (3) Aspek kepaduan dan kehematan kalimat yang digunakan pada laporan praktik kerja industri siswa dan memiliki jumlah terbanyak (urutan ketiga). Dari kalimat yang di analisis yang memenuhi syarat ketepatan kalimat berjumlah 5 dan 4 kalimat. Yang tidak memenuhi penggunaan kalimat efektif berjumlah 8 dan 7 kalimat. (4) Aspek keparalelan kalimat yang digunakan pada laporan praktik kerja industri siswa dan memiliki jumlah terbanyak (urutan keempat). Dari kalimat yang di analisis yang memenuhi syarat ketepatan kalimat berjumlah 2 kalimat. Yang tidak memenuhi penggunaan kalimat efektif berjumlah 2 kalimat. (5) Aspek kesatuan kalimat yang digunakan pada laporan praktik kerja industri siswa dan memiliki jumlah terkecil (urutan lima). Dari kalimat yang di analisis yang memenuhi syarat ketepatan kalimat berjumlah 17 kalimat. Yang tidak memenuhi penggunaan kalimat efektif berjumlah 1 kalimat.

Saran

Berdasarkan dari hasil penelitian yang telah dilaksanakan, maka saran yang ingin disampaikan adalah:

1. Diharapkan kepadapihak sekolah untuk memperhatikan setiap laporan praktik kerja industri siswa yang dihasilkan dapat mengungkapkan informasi dari laporan tersebut secara jelas dan lebih komrehensif.

2. Kepada guru-guru untuk lebih memotivasi lagi siswa-siswa agar memiliki keinginan untuk menulis dengan berbagai metode pembelajaran yang bervariasi dan menarik bagi siswa.

3. Diharapkan kepada peneliti lain, kiranya dapat mengadakan penelitan lebihlanjut dengan melihat faktor-faktor lain yang mempengaruhi kemampuan menulis laporan praktik kerja industri.

\section{DAFTAR PUSTAKA}

Akhadiah, Sabarti dkk. 1992. Pembinaan Kemampuan Menulis Bahasa Indonesia. Jakarta: Erlangga.

Arifin, E. Zainal. 1993. Bahasa yang Lugas Dalam Laporan Teknis. Jakarta: Akademika Pressindo. 
Arifin, E. Zainal dan Tasai. 2006. Cermat Berbahasa Indonesia Untuk Perguruan Tinggi. Jakarta: Akademika Pressindo.

Dalman. 2014. Keterampilan Menulis. Jakarta: PT Raja Grafindo Persada.

Djajasudarma, Fatimah. 2012. Wacana dan Pragmatik. Bandung: Refika Aditama

Finoza, Lamuddin. 2009. Komposisi Bahasa Indonesia. Jakarta: Diksi Insan Mulia.

Jay, Ros. 2006. Menulis Proposal dan Laporan. Jakarta: PT Bhuana IImu Populer Kelompok Gramedia.

Keraf, Gorys. 1997. Komposisi. Ende Flores: Nusa Indah.

Nurgiyantoro, Burhan. 2001. Penilaian dalam Pengajaran Bahasa dan Sastra. Yogyakarta: BPFE.

Pujiono, Setiyawan. 2011. Penggunaan

Strategi Catalisting untuk Meningkatkan Kemampuan
Menulis Mahasiswa JPBSI FBS UNY. Yogyakarta: UNY.

Saddhono, Kundharu dan Slamet. 2014. Pembelajaran Keterampilan Berbahasa Indonesia Teori dan Aplikasi. Yogyakarta: Graha IImu.

Sartuni, Finoza, dan Aisyah Sundari. 1984. Bahasa Indonesia Untuk Perguruan Tinggi. Jakarta: Nina Dinamika.

Sumarsono, Sonny. 2003. Teknik Penulisan Laporan. Yogyakarta: Universitas Jember.

Susetyo. 2009. Menulis Akademik. Bengkulu: Unit Penerbitan FKIP UNIB.

Tarigan, H.G. 2008. Menulis Sebagai Suatu Keterampilan Berbahasa. Bandung: Angkasa.

Widyamartayasa dan Vero Sudiati. 2005. Mahir Menulis Berbagai Laporan. Yogyakarta: Kanisius. 